\title{
Glucagon-Like Peptide-1 Receptor Agonism Improves Nephrotoxic Serum Nephritis by Inhibiting T-Cell Proliferation
}

Foteini Moschovaki Filippidou, ${ }^{*}$ Alexander H. Kirsch, ${ }^{*}$ Matthias Thelen, ${ }^{*}$ Máté Kétszeri, ${ }^{*}$ Katharina Artinger, ${ }^{*}$ Ida Aringer, ${ }^{*}$ Corinna Schabhüttl, ${ }^{*}$ Agnes A. Mooslechner, ${ }^{*}$ Bianca Frauscher, ${ }^{*}$ Marion Pollheimer, ${ }^{\dagger}$ Tobias Niedrist, ${ }^{\ddagger}$ Andreas Meinitzer, Daniel J. Drucker, ${ }^{\S}$ Thomas R. Pieber, ${ }^{\circledR}$ Philipp Eller, Alexander R. Rosenkranz, ${ }^{*}$ Akos Heinemann, ${ }^{* * \dagger \dagger}$ and Kathrin Eller*

From the Clinical Division of Nephrology, * Clinical Division of Endocrinology and Diabetology, ${ }^{\top}$ and Intensive Care Unit, ${ }^{\|}$Department of Internal Medicine, the Institute of Pathology, ${ }^{\dagger}$ the Clinical Institute of Medical and Chemical Laboratory Diagnostics, ${ }^{\ddagger}$ and the Otto Loewi Research Center, ${ }^{* *}$ Division of Pharmacology, Medical University of Graz, Graz, Austria; the Lunenfeld Tanenbaum Research Institute, ${ }^{\S}$ Mt. Sinai Hospital, University of Toronto, Toronto, Ontario, Canada; and BioTechMed, ${ }^{\dagger \dagger}$ Graz, Austria

Accepted for publication October 1, 2019.

Address correspondence to Kathrin Eller, M.D., Clinical Division of Nephrology, Department of Internal Medicine, Medical University of Graz, Auenbruggerplatz 27, A-8036 Graz, Austria. E-mail: kathrin.eller@medunigraz.at.

\begin{abstract}
Glucagon-like peptide (GLP)-1 analogs such as liraglutide improved albuminuria in patients with type 2 diabetes in large randomized controlled trials. One of the suspected mechanisms is the antiinflammatory potential of GLP-1 receptor (Glp1r) agonism. Thus, the anti-inflammatory action of Glp1r agonism was tested in a nondiabetic, T-cell-mediated murine model of nephrotoxic serum nephritis (NTS). The role of Glp1r in NTS was evaluated by using $\mathrm{Glp} 1 \mathrm{r}^{-/-}$mice or C57BL/6 mice treated with liraglutide. In vitro, murine T cells were stimulated in the presence of liraglutide or vehicle. Glp1 $1 r^{-1-}$ mice displayed increased renal infiltration of neutrophils and T cells after induction of NTS. Splenocyte proliferation and TH1 cytokine transcription were increased in spleen and lymph nodes of Glp1r $r^{-1-}$ mice. Liraglutide treatment significantly improved the renal outcome of NTS in C57BL/6 mice by decreasing renal infiltration and proliferation of $\mathrm{T}$ cells, which resulted in decreased macrophage infiltration. In vitro, T cells stimulated in the presence of liraglutide showed decreased proliferation of TH1 and TH17 cells. Liraglutide blocked glycolysis in T cells and decreased their Glut1 mRNA expression. Together, Glp1r agonism protects mice from a T-cell-dependent glomerulonephritis model by inhibition of T-cell proliferation, possibly by interacting with their metabolic program. This mechanism may explain in part the renoprotective effects of Glp1r agonism in diabetic nephropathy. (Am J Pathol 2020, 190: 400-411; https://doi.org/10.1016/j.ajpath.2019.10.008)
\end{abstract}

The gastrointestinal tract is the largest endocrine network in the human body. It translates environmental signals to multiple organ systems to maintain homeostasis. One of the most extensively studied gastrointestinal hormones is glucagon-like peptide-1 (GLP-1), an incretin hormone produced by the enteroendocrine $\mathrm{L}$ cells in the distal ileum and colon. ${ }^{1}$ It is rapidly cleared from the circulation by the kidneys and degradation by dipeptidyl peptidase IV (DPP IV). Thus, bioactive GLP-1 in humans has a half-life of $<2$ minutes. ${ }^{1}$ GLP-1 acts via the GLP-1 receptor (GLP1R), a G-protein-coupled receptor expressed widely in pancreas, gastrointestinal tract, kidneys, lung, and heart. ${ }^{2}$ GLP-1 is
Supported by Austrian Science Fund FWF grants P-27537 (P.E.) and P-22521 (A.H.), Austrian National Bank OeNB grants Nr.14263 (A.H.) and Nr.17212 (K.E.), and the Austrian Science Fund FWF (W1241) and the Medical University of Graz through the Ph.D. Program Molecular Fundamentals of Inflammation (DK-MOLIN) (F.M.F., I.A., and A.A.M.).

Disclosures: T.R.P. is an advisory board member of Novo Nordisk A/S, a consultant for Roche Diabetes Care, Novo Nordisk A/S, Eli Lilly \& Co., Infineon, Carnegie Bank, and on the speaker's bureau of Novo Nordisk A/S and AstraZeneca; D.J.D. has been a consultant to Intarcia, Merck, Novo Nordisk, Pfizer, and Sanofi Inc., and receives research funding for preclinical studies from Merck, Novo Nordisk, and Takeda Inc.

M.K. and B.F. are enrolled in the Ph.D. program in molecular medicine. 
mainly known for its ability to regulate blood glucose: it stimulates insulin secretion and contributes to glucose metabolism. ${ }^{3}$

GLP1R agonists, such as liraglutide, are already in clinical use for patients with type 2 diabetes and obesity, and have been shown to improve surrogate renal endpoints in large randomized controlled trials in type 2 diabetes patients, ${ }^{4,5}$ probably due to effects beyond improved glycemic control. GLP-1R is expressed in the kidney exclusively by pre-glomerular vascular smooth muscle cells and juxtaglomerular cells. ${ }^{2,6}$ There, GLP-1 mediates natriuresis and diuresis, alters renal hemodynamics, and decreases systemic blood pressure. ${ }^{7}$ It has been speculated that antiinflammatory capacity of GLP-1 analogs might further add to the improved renal outcomes because $\mathrm{C}$-reactive protein levels significantly decrease by $25 \%$ to $60 \%$ in patients with type 2 diabetes treated with GLP-1 analogs independent of changes in fasting glucose, body weight, and body fat. ${ }^{8}$ GLP1R is expressed on various immune cells and exerts anti-inflammatory effects, namely decreasing T-cell proliferation and increasing the number and function of regulatory $\mathrm{T}$ cells in mice and humans. ${ }^{9-11}$

So far, studies on T-cell-specific effects of GLP1R agonism in kidney disease are lacking. Nephrotoxic serum nephritis (NTS) is a murine model of immune-complex glomerulonephritis closely resembling forms of human rapid progressive glomerulonephritis. This rapidly progressive disease model is induced by the injection of rabbit antimouse glomerular basement membrane (GBM) serum and accelerated by a preceding immunization against rabbit IgG. Animals with NTS develop proteinuria within 7 days, and present proliferative and inflammatory glomerular changes, including crescent formation and kidney infiltrating leukocytes. ${ }^{12-14}$ The pathogenesis depends on $\mathrm{T}$ helper (TH) cells, type 1 and TH17 cells, which respectively recruit macrophages or neutrophil granulocytes to the kidney. ${ }^{15-17}$ Furthermore, regulatory $\mathrm{T}$ cells have been clearly shown to limit NTS. ${ }^{12,13,18}$

The authors studied the anti-inflammatory capacity of Glp1r agonism in a T-cell-dependent model of rapid progressive glomerulonephritis using $\mathrm{Glplr}^{-/}$mice and wildtype (WT) mice that were treated with liraglutide.

\section{Materials and Methods}

\section{Ethics Statement}

All animal experiments were approved by the Committee on the Ethics of Animal Experiments of the Austrian Ministry (BMWFW-66.010/0057-WF/II/3b/2014). All efforts were made to minimize animal suffering.

\section{Mice}

C57BL/6J mice were obtained from Charles River Laboratories (Sulzfeld, Germany). Glplr ${ }^{-1-19}$ were kindly provided by D.J.D. Genotyping was performed by isolation of genomic DNA using the DNeasy Blood and Tissue kit (QIAGEN, Hilden, Germany), followed by PCR using the following primers: primer A Glp1r 5' (forward, 5'-TACACAATGG GGAGCCCCTA-3'), primer B Glp1r 3' (reverse, 5'-AAGTC ATGGGATGTGTCTGGA-3'), primer C Neo1 (forward, 5'-CTTGGGTGGAGAGGCTATTC-3'), and primer D Neo2 (reverse, 5'-AGGTGAGATGACAGGAGATC-3'). For respective experiments, $\mathrm{Glplr}^{-/-}$mice and littermate WT controls were used. Mice were housed in a pathogen-free facility and maintained on a 12-hour light-dark cycle, with free access to standard rodent chow and water. Eight- to 12 -week-old male mice were used for all experiments. Mice weighed between 19 and $24 \mathrm{~g}$ without significant differences between groups and experiments. Mice were healthy without any bacterial or viral infections as evaluated quarterly by the animal facility.

Mice were injected intraperitoneally with $200 \mu \mathrm{g} / \mathrm{kg}$ bodyweight liraglutide (once daily) (Victoza; NovoNordisk, Bagsvaerd, Denmark) or vehicle (saline) starting on the day of immunization.

\section{Induction of NTS}

NTS was induced as described previously. ${ }^{20}$ Briefly, mice were preimmunized subcutaneously with $100 \mu \mathrm{L}$ of $2 \mathrm{mg} /$ $\mathrm{mL}$ rabbit IgG (Jackson ImmunoResearch Laboratories, West Grove, PA) dissolved in incomplete Freund's adjuvant (Sigma, St. Louis, MO) and nonviable desiccated Mycobacterium tuberculosis H37a (Difco Laboratories, Detroit, MI). After 3 days, heat-inactivated rabbit anti-mouse GBM antiserum was injected via the tail vein.

\section{Detection of Urinary Albumin and Creatinine}

Urinary albumin excretion was determined by a doublesandwich enzyme-linked immunosorbent assay (ELISA) (Abcam, Cambridge, MA). Urinary creatinine was quantified using a picric acid-based method (Sigma-Aldrich, St. Louis, MO) or by liquid chromatography tandem mass spectrometry. For the later, separations were achieved on a Hypercarb column (Thermo Fisher Scientific, San Jose, $\mathrm{CA}$ ), and detection was performed by positive electrospray ionization on a SCIEX QTRAP 4500 triple quadrupole instrument (SCIEX, Framingham, MA).

\section{Histomorphologic Evaluation of Renal Pathology}

Formalin-fixed renal tissue was embedded in paraffin and cut into 4- $\mu \mathrm{m}$ sections. The sections were stained with periodic acid-Schiff (PAS), and a minimum of 50 glomerular cross sections were evaluated per sample. The evaluation was performed as previously described. ${ }^{21}$ In brief, PASpositive material was scored within glomeruli following a semiquantitative scoring system with a scale from 0 to 3 . Cell proliferations in the different glomerular compartments 
were assessed as follows: Mesangial hypercellularity was subclassified as mild (score 1), 4 to 5 cells/mesangial area; moderate (score 2), 5 to 6 cells/mesangial area; and severe (score 3), >6 cells/mesangial area. Endocapillary hypercellularity, defined as hypercellularity due to increased number of cells within glomerular capillary lumina, was subclassified as mild (score 1), present in single glomeruli; moderate (score 2), $<50 \%$; and severe (score 3), $>50 \%$ affected glomeruli. Extracapillary hypercellularity/crescents defined as cell proliferation of more than two cell layers were subclassified as mild (score 1), present in single glomeruli; moderate (score 2), <50\%; and severe (score 3), $>50 \%$ affected glomeruli. For detecting proliferating cells in kidneys, slides were stained with mouse anti-human/ mouse/rat proliferation cell nuclear antigen (PCNA) antibody (clone PC10, BioLegend, San Diego, CA) using threelayer immunoperoxidase staining. The M.O.M. Immunodetection Kit for detecting mouse primary antibodies on mouse tissue was used (Vector Laboratories, Burlingame, CA). Glomerular $\mathrm{PCNA}^{+}$cell quantitation was performed by counting the positive cells in 50 glomeruli per sample and further calculating the average number of positive cells per glomerulus. Periglomerular $\mathrm{PCNA}^{+}$cells were quantified by counting the number of positive cells located in the periglomerular region in six adjacent high-power fields of renal cortex. To evaluate fibrotic changes, kidney sections were stained with Picrosirius Red (Sigma-Aldrich). Investigators were blinded to the samples before evaluation (F.M.F., A.H.K., M.T., M.P.).

\section{Immunofluorescence Staining of Kidney Sections}

For the detection of autologous and heterologous IgG deposition in kidneys, $4-\mu \mathrm{m}$ frozen kidney sections were stained by direct immunofluorescence staining. Fluorescein isothiocyanate-conjugated goat anti-mouse IgG (Jackson ImmunoResearch Laboratories) and fluorescein isothiocyanate-conjugated goat anti-rabbit IgG (Jackson ImmunoResearch Laboratories) were used in 1:800 dilution. Slides were mounted in a mounting medium for fluorescence (Vector Laboratories, Burlingame, CA). Slides were analyzed on a LSM510 META (Zeiss, Oberkochen, Germany).

\section{Immunomorphologic Evaluation of Infiltrating Renal Immune Cells}

The three-layer immunoperoxidase staining of 4-mm frozen tissue sections was used for the detection of macrophage, $\mathrm{T}$ cell, and neutrophil subpopulations in the kidney. Macrophages were stained with rat anti-mouse anti-CD68 antibody (clone FA-11, Bio-Rad Laboratories, Hercules, CA). A semiquantitative scoring system for kidney-infiltrating macrophages was performed as follows: 0,0 to 4 cells stained positive; 1,5 to 10 cells; 2,10 to 50 cells; 3,50 to 200 cells; and $4,>200$ cells stained positive per low-power field. For the detection of T helper cells, cytotoxic T cells, and neutrophils, rat anti-mouse anti-CD4 (clone YTS191.1, Bio-Rad Laboratories), rat anti-mouse anti-CD8 (clone KT15, Bio-Rad Laboratories), and rat anti-mouse anti-neutrophil (clone NIMP-R14, Abcam) antibodies were used, respectively. $\mathrm{T}$-cell and neutrophil quantitation was performed by counting the number of positive cells in six adjacent high-power fields of renal cortex and medulla. For all evaluations, a biotinconjugated goat anti-rat IgG (Jackson ImmunoResearch Laboratories) was used as a secondary antibody. Investigators were blinded to the samples before evaluation (F.M.F., A.H.K., M.T.).

\section{Real-Time RT-PCR}

Total RNA was isolated from kidneys, spleens, and inguinal lymph nodes using TRI Reagent (Sigma-Aldrich). Subsequently, $2 \mu \mathrm{g}$ of total RNA was reverse transcribed using $\mathrm{Su}-$ perscript III Transcription Kit (Invitrogen, Carlsbad, CA) and random primers (Invitrogen). Real-time PCR was performed in duplicates on a CFX96 Real-Time System (BioRad) using TaqMan gene expression assays (Applied Biosystems, Foster City, CA) for Il-10 (Mm00439616_m1), Il-6 (Mm00446190_m1), interferon- $\gamma$ (Ifn- $\gamma)($ Mm00801778_m1), Tnf- $\alpha$ (Mm00443258_m1), Tbet (Mm00450960_m1), Roryt (Mm012611022_m1), Gata3 (Mm00484683_m1), and Foxp3 (Mm00475162_m1). Hprt was used as the reference gene for kidney and spleen tissues, whereas for lymph node tissue, Rpl0 was used. The primers were, respectively: forward 5'-GCTTCCTCCTCAGACCGCTTTTTGC-3'; reverse 5'-ATCGCTAATCACGACGCTGGGACTG-3'; forward 5'TTGGCCAATAAGGTGCCAGC- $3^{\prime}$; and reverse $5^{\prime}$-CTCGG GTCCTAGACCAGTGT- $3^{\prime}$. Both reference genes, as well as the CollAl gene (primers: forward 5'-CAATGCAATGAAGAAC TGGACTGT-3'; reverse 5'-TCCTACATCTTCTGAGTTTGG TGA-3'), were assessed using SYBR Green Master Mix (Invitrogen). The data were evaluated using the $2 \Delta \Delta C T$ method.

\section{Flow Cytometry}

Cell suspensions from lymph nodes were stained with antibodies against $\mathrm{CD} 4, \mathrm{CD} 25$, and FoxP3 according to the manufacturer's instructions (BioLegend). Samples were analyzed on LSRII and FACSCalibur cytometers (both BD Biosciences, San Jose, CA).

\section{Cell Culture Experiments}

Splenocytes were isolated from WT and $\mathrm{Glplr}^{-/-}$mice subjected to NTS for 14 days. Briefly, spleen specimens were minced and suspended after passage through a $70-\mu \mathrm{m}$ cell strainer. The cells were stimulated with $100 \mu \mathrm{g} / \mathrm{mL}$ precoated rabbit IgG or $200 \mathrm{ng} / \mathrm{mL}$ lipopolysaccharides for 24 and 16 hours, respectively. The proliferation of the cells was evaluated with the EZ4U cell proliferation assay (Biomedica, Vienna, Austria). T cells were isolated from spleens of C57BL/6J as well as $\mathrm{Glplr}^{-/-}$mice and WT littermates using the MagniSort 
Mouse T cell Enrichment Kit (Invitrogen). The cells were stimulated with anti-CD3/CD28 antibodies (eBioscience, San Diego, CA) and treated with liraglutide $(60 \mu \mathrm{g} / \mathrm{mL})$ for 72 hours. The anti-mouse CD3e antibody (clone 145-2C11) was coated on the plates in a concentration of $5 \mu \mathrm{g} / \mathrm{mL}$ and incubated overnight at $4^{\circ} \mathrm{C}$. Anti-mouse $\mathrm{CD} 28$ was added to the cells in a concentration of $2 \mu \mathrm{g} / \mathrm{mL}$. Ifn- $\gamma$, Il-6, Il-10, Il-17, Il-4, and Tnf- $\alpha$ levels in the supernatant of the cells were determined using commercially available ELISA kits (BD Biosciences). Glycolysis in $\mathrm{T}$ cells was measured using the Enzychrom Glycolysis Assay kit (BioAssay Systems, Hayward, CA). For the TH1 and TH17 polarization, cells were isolated from spleens of $\mathrm{C} 57 \mathrm{BL} / 6 \mathrm{~J}$ mice using the $\mathrm{CD} 4{ }^{+} \mathrm{CD} 2 \mathrm{~L}^{+} \mathrm{T}$ cell isolation kit (Miltenyi Biotec, Bergisch Gladbach, Germany). TH1 stimulation was achieved as follows: the anti-mouse CD3e antibody (clone 145-2C11) was coated on the plates in a concentration of $2.5 \mu \mathrm{g} / \mathrm{mL}$ and incubated overnight at $4^{\circ} \mathrm{C}$. Anti-mouse CD28 (eBioscience), anti-mouse Il-4 (BioLegend), recombinant mouse Il-2 (BioLegend), and recombinant mouse Il-12 (BioLegend) were added to the cells in the following concentrations, respectively: $3 \mu \mathrm{g} / \mathrm{mL}, 10 \mu \mathrm{g} / \mathrm{L}, 5$ $\mathrm{ng} / \mathrm{mL}$, and $10 \mathrm{ng} / \mathrm{mL}$. Cells were incubated for 5 days. For TH17 polarization, the cells were kept in culture for 4 days with the addition of anti-mouse CD28 (eBioscience), anti-mouse Il4 (BioLegend), anti-mouse Ifn- $\gamma$ (BioLegend), recombinant mouse Il-23 (BioLegend), recombinant mouse Il-6
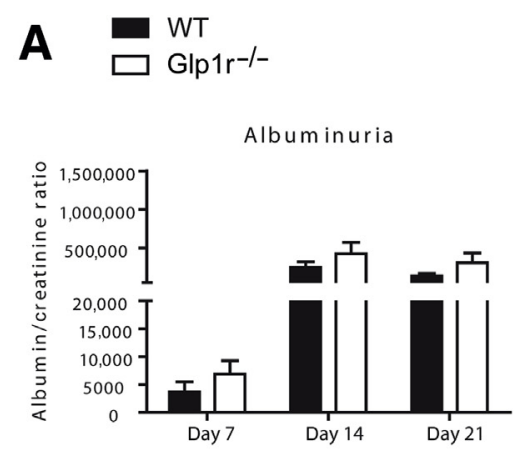

B
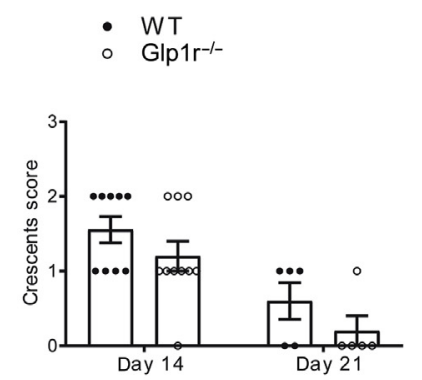

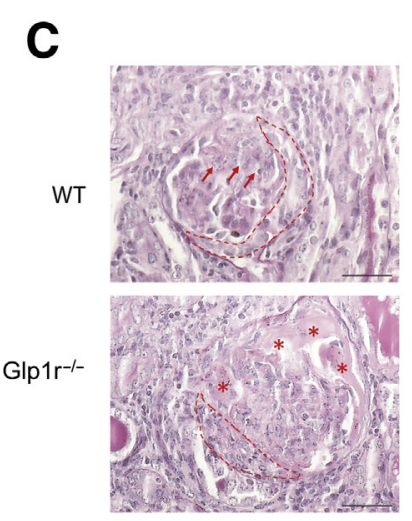

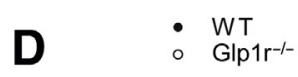

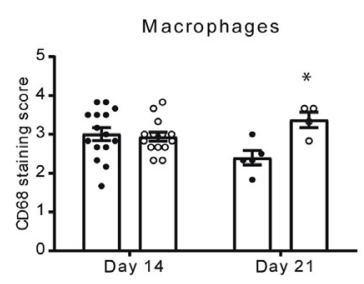

E

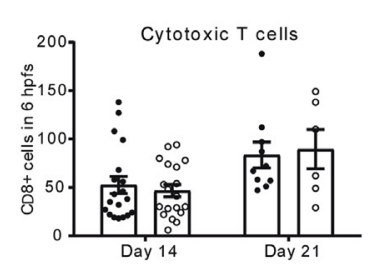

$\mathbf{F}$

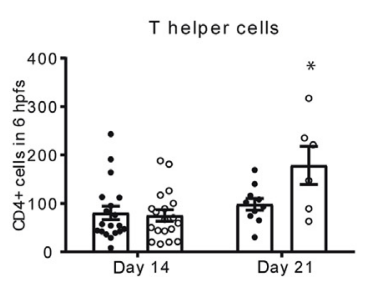

G

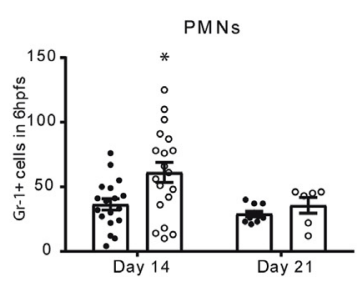

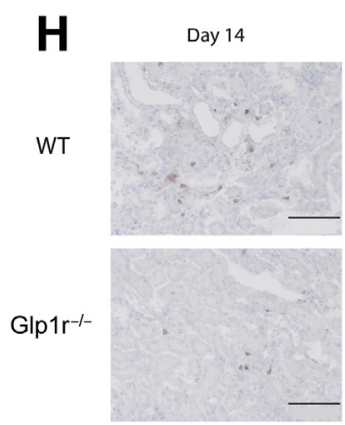
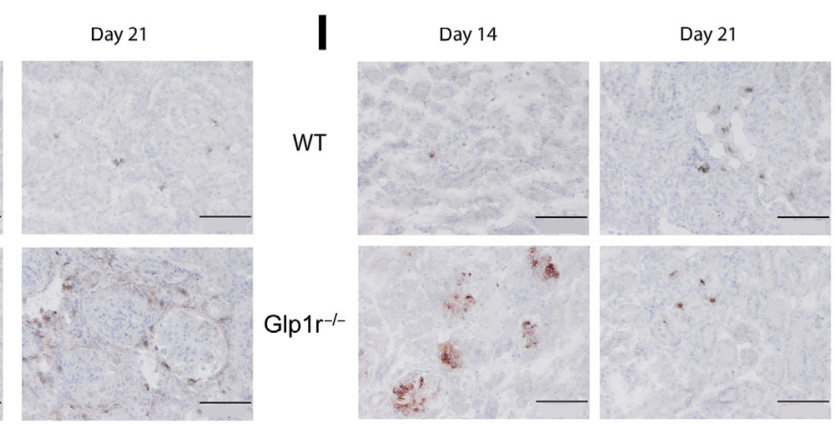

Figure $1 \mathrm{Glp} 1 \mathrm{r}^{-/-}$mice show increased renal infiltration of inflammatory cells after NTS induction. WT and Glp $1 r^{-/-}$mice were subjected to NTS for 7 days, 14 days, and 21 days. A: Urinary albumin/creatinine ratios $(\mu \mathrm{g} / \mathrm{mg})$ were evaluated at indicated time points after NTS induction. B: Kidney sections were quantified for crescent formation. C: Representative PAS-stained kidney sections of WT and Glp1r ${ }^{-/}$mice 14 days after NTS induction. Dashed lines indicate cellular crescent formation; asterisks, fibrin deposition within Bowman space; and arrows, endocapillary hypercellularity with significant proliferation of endocapillary cells within the glomerular capillary loops. D-G: Kidney sections were analyzed for the infiltration of $\mathrm{CD}^{+} 8^{+}$macrophages (D), and CD8 ${ }^{+}$ cytotoxic (E) and $\mathrm{CD}^{+}{ }^{+}$T helper cells (F), as well as polymorphonuclear granulocytes (PMN) (G). H and I: Representative pictures from kidney sections stained for $\mathrm{CD4}^{+} \mathrm{T}$ cells (H) and PMNs (I) after 14 and 21 days of NTS are shown. $n=6 \mathrm{Glp} 1 \mathrm{r}^{-/-}$mice treated 21 days; $n=9$ WT mice treated 21 days; $n=13$ mice per group treated 7 days; $n=18 \mathrm{Glp} 1 r^{-/-}$mice treated 14 days; $n=19$ WT mice treated 14 days. ${ }^{*} P<0.05$ versus WT. Scale bars: $50 \mu \mathrm{m}(\mathbf{C}) ; 100 \mu \mathrm{m}(\mathbf{H}$ and I). Original magnification: $\times 600(\mathbf{C}) ; \times 200($ H and I). hpf, high-power field. 
(Immunotools, Friesoythe, Germany), and recombinant human TGF- $\beta$ (Immunotools) in the concentrations: $1 \mu \mathrm{g} / \mathrm{mL}$, $10 \mu \mathrm{g} / \mathrm{mL}, 10 \mu \mathrm{g} / \mathrm{mL}, 10 \mathrm{ng} / \mathrm{mL}, 40 \mathrm{ng} / \mathrm{mL}$, and $5 \mathrm{ng} / \mathrm{mL}$, respectively. The plate had been coated beforehand with antimouse CD3e antibody (clone 145-2C11) as described for the TH1 stimulation but in a concentration of $0.5 \mu \mathrm{g} / \mathrm{mL}$. The proliferation of the cells was evaluated with the EZ4U cell proliferation assay (Biomedica). To verify the success of the polarization, Ifn- $\gamma$ and Il-17 levels in the supernatant of the cells were determined using commercially available ELISA kits (BD, San Jose, CA). Furthermore, to investigate the expression of Glpl $r$ in lymphocytes, T cells were isolated from spleens and lymph nodes of C57B1/6 and $\mathrm{Glplr}^{-1-}$ mice using the MagniSort Mouse T cell Enrichment Kit (Invitrogen). The cells were stimulated for 72 hours with aCD3/CD28 stimulation (as described above), or used directly for RNA isolation. RNA was isolated from the cells using the RNeasy Mini Kit (QIAGEN). Subsequently, $2 \mu \mathrm{g}$ of total RNA was reverse transcribed using Superscript III Transcription Kit (Invitrogen) and random primers (Invitrogen). PCR was performed using primers for Glplr and $\beta$-actin (forward 5'-GGCCATGTGTACCGGTTCTG-3'; ${ }^{\prime}$ reverse $5^{\prime}$-GGTGC AGTGCAAGTGTCTGA- $3^{\prime}$; forward 5'-GAAGTGTGACG TTGACATCCG-3'; reverse $5^{\prime}$-TGCTGATCCACATCTGC TGGA- $3^{\prime}$, respectively). The PCR products were loaded on a $2 \%$ agarose gel and run at $80 \mathrm{~V}$ for 50 minutes. A no template control was used as a negative control. As a positive control, cDNA synthesized from $2 \mu \mathrm{g}$ RNA isolated from mouse brain was used. Finally, the gene expression of Glut-1 has been monitored using TaqMan gene expression assays (Mm00441473_m1). Rpl29 was used as a reference gene (primers: forward 5'-CGCGGGTTACCGTGAGTGT-3'; reverse $5^{\prime}$-TGTCTGCACCTCGCGACC- $3^{\prime}$ ) and was assessed using SYBR Green Master Mix (Invitrogen).

\section{Statistical Analysis}

Data are presented as means \pm SEM. The normal distribution of the data was assessed by the Kolmogorov-Smirnov test with Dallal-Wilkinson-Lilliefors correction or the Shapiro-Wilk normality test. When comparing two groups, according to the distribution, an unpaired $t$-test or a $U$-test was used. When comparing scores, the $\chi^{2}$ test was used. $P<0.05$ was considered statistically significant. All statistical analyses were performed using GraphPad Prism software version 7.0 (GraphPad Software, La Jolla, CA).

\section{Results}

\section{Glp $1 r^{-/-}$Mice Demonstrate an Increased Renal Infiltration of Immune Cells after NTS Induction}

To evaluate the role of Glp1r in NTS, the disease was induced in $\mathrm{Glplr}^{-/-}$mice and WT mice. Mice developed NTS within the observed time period of 21 days as shown by albuminuria, without a difference between the two groups (Figure 1A and Supplemental Table S1). As expected from previous studies, ${ }^{12-14}$ mice displayed glomerular hypercellularity, endothelial cell proliferation, focal deposits, and crescent formation in about $10 \%$ to $20 \%$ of glomeruli, but differences were not observed in histologic changes between the two groups after 14 days (Figure 1, B and C, Supplemental Table S1, Supplemental Figure S1, and Supplemental Table S2) and 21 days of NTS (Figure 1B and Supplemental Figure S1). Of note, relevant glomerular scarring was not observed during the observation period of

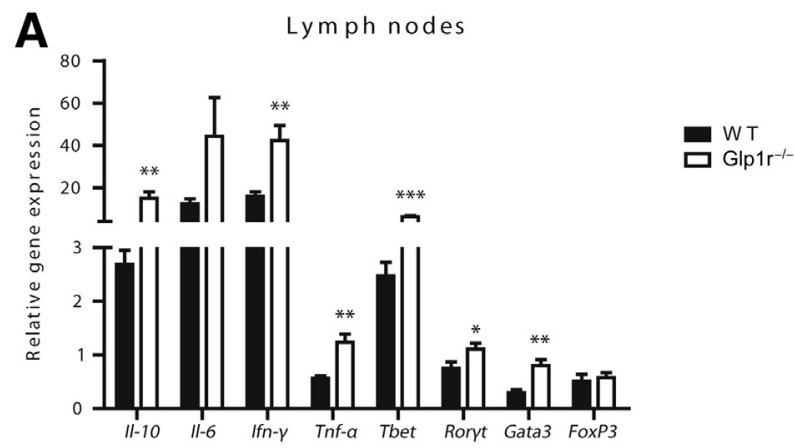

B

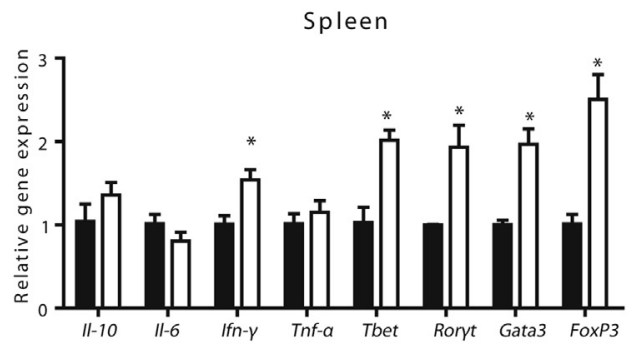

C

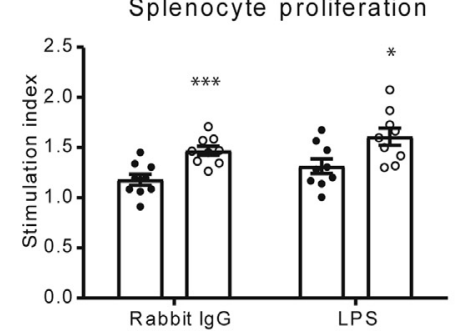

- WT

- $\mathrm{Glp} 1 \mathrm{r}^{-1-}$

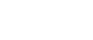

Figure 2 Increased systemic inflammation is observed in $\mathrm{Glp}_{1} \mathrm{r}^{-/}$ mice. A: The mRNA expression of inflammatory genes was evaluated in inguinal lymph nodes of WT and Glp1r ${ }^{-/}$mice 14 days after NTS induction. The fold increase compared with the mean mRNA expression in healthy WT and $G l p 1 r^{-/}$mice is provided. B: The mRNA expression of respective genes was evaluated in the spleens of WT and Glp1r ${ }^{-/-}$mice after 14 days of NTS. The fold increase compared with the mean mRNA expression in diseased WTs is provided. C: Splenocytes were isolated from WT and $G l p 1 r^{-/-}$mice after 14 days of NTS. Cells were stimulated in vitro by rabbit IgG and lipopolysaccharides coated on the plates, and proliferation was evaluated. The stimulation index is given as the ratio between the optical density values of stimulated to unstimulated cells. $n=8$ WT mice $(\mathbf{A}) ; n=10$

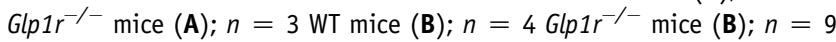
mice per group (C). ${ }^{*} P<0.05,{ }^{* *} P<0.01$, and ${ }^{* *} P<0.001$ versus WT. 
21 days (data not shown). The infiltration of $\mathrm{CD}^{+} 8^{+}$macrophages and $\mathrm{CD} 4^{+} \mathrm{T}$ cells was significantly higher in Glp1r ${ }^{-/}$mice after 21 days of NTS, whereas no difference was noted between the two groups on day 14 (Figure 1, D, F, and H, and Supplemental Table S1). No difference was observed in the infiltration of $\mathrm{CD} 8^{+} \mathrm{T}$ cells throughout the observation period (Figure 1E, and Supplemental Table S1). Fourteen days after induction of NTS, a significant increase was observed in renal infiltration of polymorphonuclear granulocytes in $\mathrm{Glplr}^{-/}$mice compared with WT mice. This difference was lost by day 21 after disease induction (Figure 1, G and I, and Supplemental Table S1). No difference was detected in the linear deposition of mouse and rabbit IgG on the glomerular membrane 14 days after NTS induction (Supplemental Figure S2).

\section{The Expression of Inflammatory Genes Is Increased in Lymph Nodes and Spleens of Glp1r ${ }^{-/-}$Mice in NTS}

Cytokine expression profiling by real-time quantitative PCR in inguinal lymph nodes of wild-type and $\mathrm{Glplr}^{-1-}$ mice after 14 days of NTS revealed increased mRNA expression of Il-10, Ifn- $\gamma$, and Tnf- $\alpha$ in Glplr ${ }^{-1-}$ mice as compared with WT controls. Additionally, the expression of TH17 marker Rorrt and TH1 and TH2 master regulator Tbet and Gata 3 was up-regulated in the lymph nodes of $\mathrm{Glplr}^{-/-}$mice (Figure 2A and Supplemental Table S3). The same genes were also evaluated in the spleens of those mice. In detail, the expression of Ifn- $\gamma$, Tbet, Ror $\gamma$ t, Gata3, and Foxp3 was up-regulated in the spleens of $\mathrm{Glplr}^{-/-}$mice (Figure 2B and Supplemental Table S3). In further experiments, splenocytes isolated from WT and $\mathrm{Glplr}^{-1-}$ mice 14 days after NTS induction were cultured and stimulated with rabbit IgG or lipopolysaccharides coated on the plates. Both stimulation methods significantly increased proliferation of splenocytes isolated from $\mathrm{Glplr}^{-/-}$mice as compared with WT mice (Figure 2C and Supplemental Table S3). Of note, $\mathrm{CD} 4{ }^{+} \mathrm{CD} 25^{+} \mathrm{FoxP}^{+}$regulatory $\mathrm{T}$ cell (Tregs) evaluated by flow cytometry in lymph nodes did not differ between the two groups either in absolute or in relative numbers (Supplemental Figure S3, A and B, and Supplemental Table S4). No difference was seen in gene expression profiles of TH1, TH2, TH17, and Treg markers in the kidneys of Glp1r ${ }^{-1-}$ and WT mice 14 days after NTS induction (data not shown).

Interestingly, cytokine gene expression in lymph nodes differed significantly between healthy $\mathrm{Glplr}^{-/-}$mice and WT controls. Glplr ${ }^{-1-}$ mice displayed a decreased cytokine mRNA expression profile of TH1, TH2, and Treg markers. Only the TH17 marker Roryt did not differ between the two groups (Supplemental Figure S4 and Supplemental Table S5). No difference was detected in cytokine mRNA transcription levels in the kidneys of healthy $\mathrm{Glplr}^{-/-}$and WT mice (data not shown).

\section{Glp1r Agonism by Liraglutide Protects Mice from NTS}

Because Glp1r signaling has been implicated in having immunomodulatory effects, which were also shown in
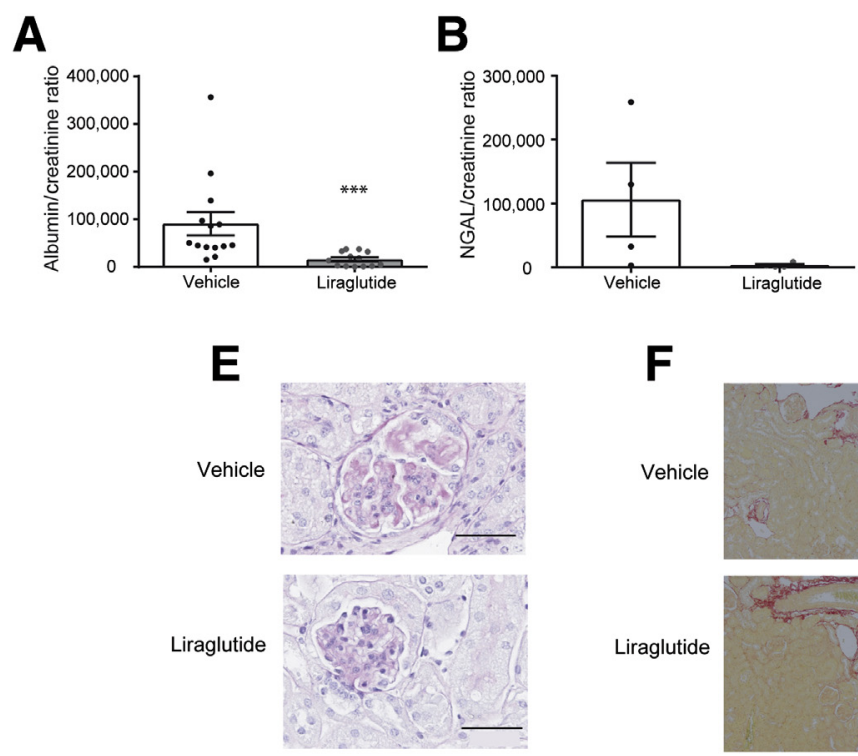
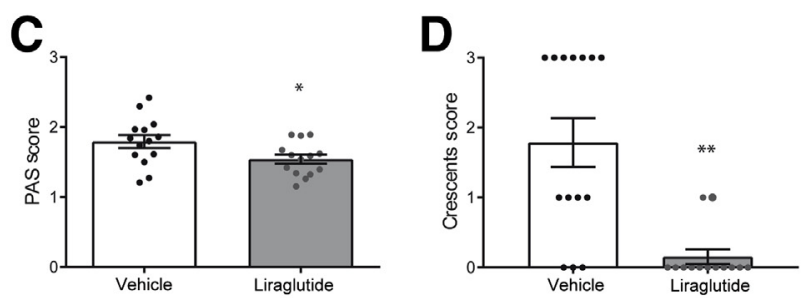

\section{G}
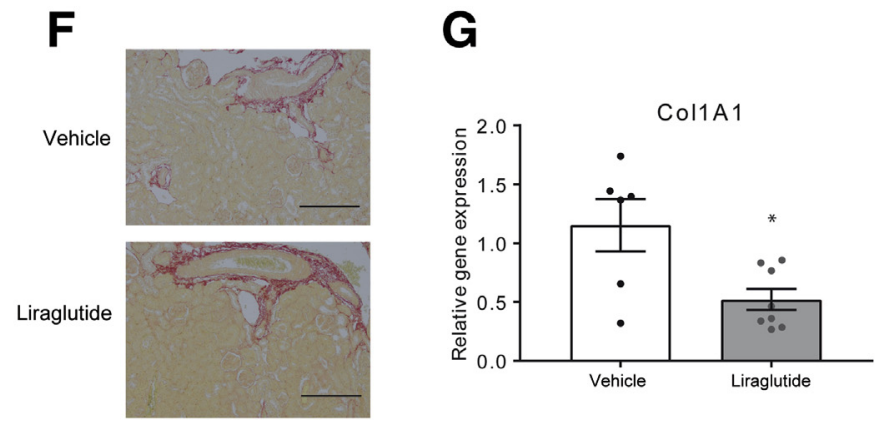

Figure 3 Liraglutide protects mice from NTS. WT mice were subjected to NTS for 14 days and treated with vehicle or liraglutide from the day of immunization. A: Urinary albumin/creatinine ratios $(\mu \mathrm{g} / \mathrm{mg})$ were evaluated on day 14 after NTS induction. B: At the same time point, urinary NGAL/creatinine ratios (pg/mg) were evaluated. C and D: Kidney sections were quantified for PAS-positive deposits (C) and for crescent formation (D). E: Representative PAS-stained kidney sections of mice treated with vehicle or liraglutide. F: Representative pictures for Picrosirius Red stain of the kidneys. G: The mRNA expression of the Col1A1 gene was evaluated in the kidneys of the mice. The fold increase compared with the mean mRNA expression in vehicle-treated mice subjected to NTS is provided. $n=13$ liraglutide-treated mice $(\mathbf{A}, \mathbf{C}$, and $\mathbf{D}) ; n=14$ vehicle-treated mice $(\mathbf{A}, \mathbf{C}$, and $\mathbf{D}) ; n=4$ mice per group (B); $n=6$ vehicle-treated mice $(\mathbf{G}) ; n=8$ liraglutide-treated mice $(\mathbf{G})$. ${ }^{\star} P<0.05,{ }^{*} P<0.01$, and ${ }^{* * *} P<0.001$ versus vehicle. Scale bars: $50 \mu \mathrm{m}(\mathbf{E}) ; 200 \mu \mathrm{m}(\mathbf{F})$. Original magnification: $\times 400(\mathbf{E}) ; \times 100(\mathbf{F})$. 
$\mathrm{Glplr}^{-/-}$mice subjected to NTS, C57BL/6 mice were treated with the Glp1r agonist liraglutide starting on the day of NTS induction. On day 14 after NTS induction, albuminuria as well as urinary neutrophil gelatinase-associated lipocalin (NGAL) levels were significantly lower in mice treated with liraglutide as compared with vehicle-treated mice (Figure 3, A and B, and Supplemental Table S6). In line with the difference in albuminuria, kidney histology revealed more severe renal damage in vehicle-treated mice than in liraglutide-treated mice, which was quantified by scoring PAS-positive deposits and crescents in glomeruli (Figure 3, C-E, and Supplemental Table S6). Further histomorphologic evaluation revealed significantly decreased glomerular and tubular changes in liraglutide-treated mice compared with vehicle-treated controls (Supplemental Figure S5, and Supplemental Table S7). Only marginal fibrotic changes were observed in kidneys subjected to 14 days of NTS (Figure 3F and Supplemental Table S6), but mRNA expression collagen type I alpha 1 chain (CollAl) as a marker for fibrosis was significantly decreased in liraglutide-treated mice as compared with vehicle-treated controls (Figure 3G and Supplemental Table S6). Of note, no differences were found for CollAl mRNA expression in kidneys of $\mathrm{Glplr}^{-/-}$and WT mice 14 days after NTS induction (data not shown). At the same time point, a significant decrease was observed in renal infiltration of $\mathrm{CD} 8^{+}$macrophages, $\mathrm{CD} 8^{+}$cytotoxic $\mathrm{T}$ cells, and $\mathrm{CD} 4^{+} \mathrm{TH}$ cells in liraglutide-treated mice as compared with vehicle-treated controls (Figure 4, B-E, and Supplemental Table S8). A trend was detected toward fewer infiltrating polymorphonuclear granulocytes in the liraglutide group (Figure 4A and Supplemental Table S8). Consistent with these findings, the expression of several inflammatory genes related to TH1 cells and Tregs was decreased in kidneys of mice treated with liraglutide compared with vehicle-treated controls (Figure 4F and Supplemental Table S8). By contrast, no difference was noted in the expression of the TH17 marker Ror $\gamma t$ and the TH2 marker Gata3. Of note, proliferating cells in glomeruli as well as within the periglomerular region
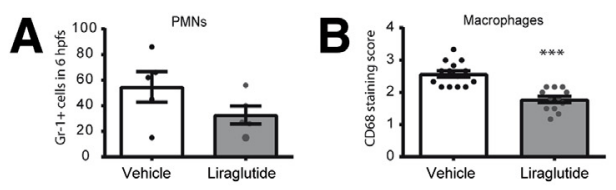

$\mathbf{E}$
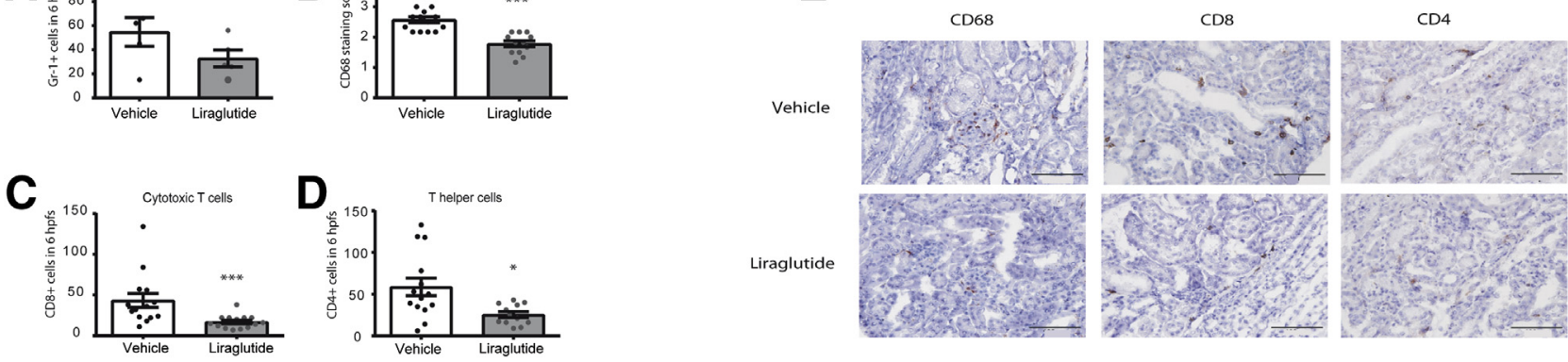

G

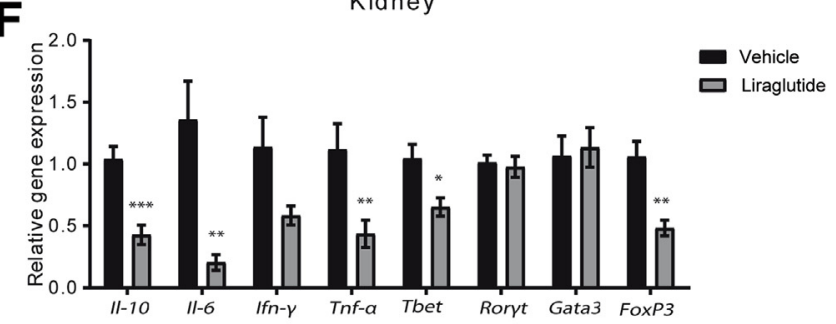

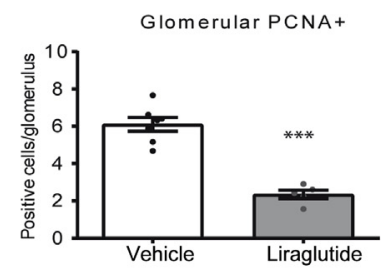

H

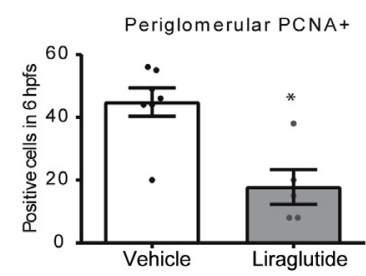

\section{I}

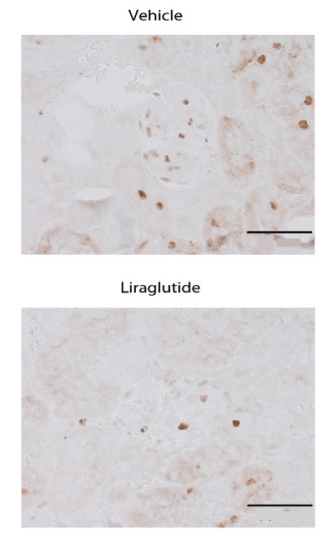

Figure 4 Liraglutide decreases renal inflammatory cell infiltration. WT mice were subjected to NTS for 14 days and treated with vehicle or liraglutide from the day of immunization. A-D: Kidney sections were analyzed for PMNs (A), CD68 ${ }^{+}$macrophages (B), CD8 ${ }^{+}$ cytotoxic T cells (C), and $\mathrm{CD}^{+}{ }^{+} \mathrm{TH}$ cells (D). E: Representative pictures from kidney sections from vehicle- and liraglutide-treated mice stained for the respective markers after 14 days of NTS. F: Quantitative PCR of respective genes was performed on kidney tissues of mice subjected to NTS for 14 days treated with either vehicle or liraglutide. The fold increase compared with the mean mRNA expression in vehicle-treated mice subjected to NTS is provided. $\mathbf{G}$ and $\mathbf{H}$ : Kidneys were stained for proliferating cells by using PCNA stain. Positive cells in glomeruli $(\mathbf{G})$ and the periglomerular region $(\mathbf{H})$ were counted. I: Representative pictures for PCNA stain in the kidneys are shown. $n=13$ liraglutide-treated mice (A-D); $n=14$ vehicle-treated mice $(\mathbf{A}-\mathbf{D}) ; n=8$ liraglutide-treated mice $(\mathbf{F}) ; n=9$ vehicletreated mice $(\mathbf{F})$. ${ }^{*} P<0.05,{ }^{*} P P<0.01$, and ${ }^{* * *} P<0.001$ versus vehicle. Scale bars: $100 \mu \mathrm{m}(\mathrm{E}) ; 50 \mu \mathrm{m}$ (I). Original magnification: $\times 200(\mathbf{E}) ; \times 400$ (I). hpf, high-power field. 
detected by PCNA stain were significantly decreased in kidneys of liraglutide-treated mice compared with controls (Figure 4, G-I, and Supplemental Table S8). No difference was detected in the linear deposition of mouse and rabbit IgG on the glomerular membrane 14 days after NTS induction (Supplemental Figure S2).

\section{Liraglutide Acts via the Glp1r to Improve NTS}

To prove whether the immunosuppressive effects of liraglutide in NTS are signaled via the Glp1r, Glplr ${ }^{-1-}$ mice were subjected to NTS for 14 days, and they were treated with liraglutide or vehicle starting on the day of disease induction. Neither albuminuria (Figure 5A and Supplemental Table S9) nor renal immune cell infiltration (Figure 5, B-E, and Supplemental Table S9) differed significantly between the two groups 14 days after NTS induction. Additionally, no differences were noted in the renal histology or the expression of inflammation-related genes in the kidney (data not shown).

\section{Liraglutide Inhibits the Proliferation of Stimulated Mouse TH1 and TH17 Cells}

To prove whether the Glp1r agonist liraglutide decreases Tcell proliferation, $\mathrm{T}$ cells were isolated from spleens of C57BL/6J mice, stimulated with aCD3/CD28, and treated with liraglutide. T-cell proliferation was significantly inhibited by liraglutide as compared with vehicle (Figure 6 and Supplemental Table S10), whereas liraglutide did not influence proliferation of $\mathrm{T}$ cells isolated from $\mathrm{Glplr}^{-/-}$ mice as compared with WT littermate controls (Figure 6 and Supplemental Table S10). No differences were found in the protein levels of Il-4, Ifn- $\gamma$, Il-17, Tnf- $\alpha$, and Il-10 between supernatants of treated and untreated cells (Figure 6 and Supplemental Table S10). Only the amount of Il-6 was significantly lower in the supernatant of $\mathrm{T}$ cells treated with liraglutide (Figure 6 and Supplemental Table S10). Of note, $\mathrm{T}$ cells transcribed the Glplr mRNA before and after stimulation (Supplemental Figure S6). Furthermore, T cells from C57BL/6J mice were polarized into TH1 and TH17 cells in vitro (Supplemental Figure S7, B and C, and Supplemental Table S11), and proliferation was evaluated in the presence or absence of liraglutide. Liraglutide significantly decreased proliferation of TH1 and TH17 polarized cells (Figure 6 and Supplemental Table S10). Glplr mRNA was detected in both $\mathrm{TH} 1$ and TH17 polarized cells (Supplemental Figure S7A and Supplemental Table S11).

\section{Liraglutide Influences Glucose Metabolism in T Cells}

$\mathrm{T}$ cells isolated from the spleens of C57BL/6J mice were stimulated with aCD3/CD28 and treated with liraglutide. L-lactate as a marker for glycolysis was measured after 72 hours with normalization to cell numbers. L-lactate was found to be significantly decreased in stimulated $\mathrm{T}$ cells
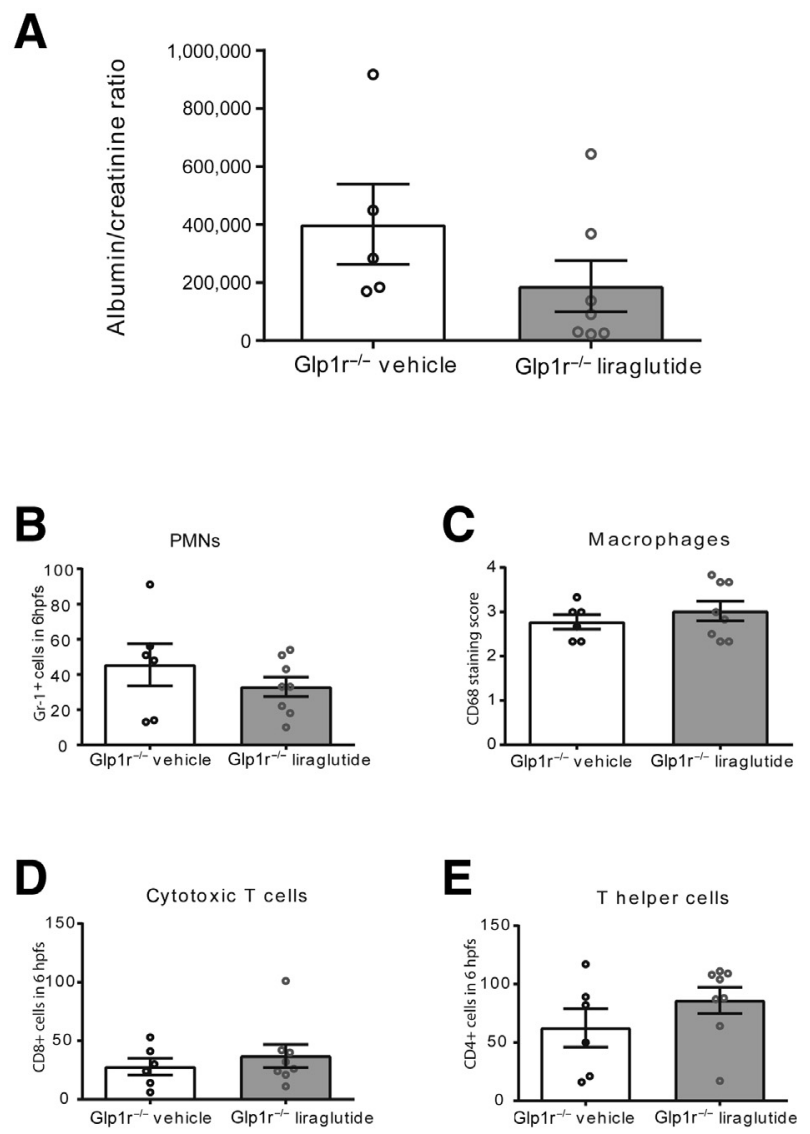

Figure 5 Liraglutide treatment has no effect on $\mathrm{Glp}_{1 r^{-/}}$mice subjected to NTS. Glp1 $r^{-/-}$mice were subjected to NTS for 14 days and treated with vehicle or liraglutide from the day of immunization. A: Urinary albumin/creatinine ratios were evaluated on day 14 after NTS induction. B-E: Kidney sections were analyzed for PMNs (B), $\mathrm{CD}^{+} 8^{+}$macrophages (C),

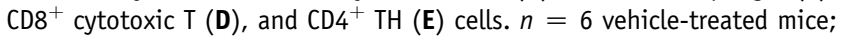
$n=8$ liraglutide-treated mice. hpf, high-power field.

treated with liraglutide (Figure 7 and Supplemental Table S12). Stimulated $\mathrm{T}$ cells were additionally analyzed for the mRNA expression of the glucose transporter Glut-1. Liraglutide significantly reduced the mRNA expression of Glut-1 in stimulated T cells.

\section{Discussion}

This study provides evidence that Glp1r agonism by liraglutide suppresses T-cell proliferation and thereby leads to a significant improvement of a T-cell-mediated kidney disease, namely NTS, which closely resembles human forms of immunocomplex-mediated rapid progressive glomerulonephritis. These data provide additional evidence about in vivo effects of Glp1r agonism that go beyond blood glucose-lowering effects.

These data are highly relevant from a clinical perspective because large randomized controlled trials using Glp1r analogs, namely liraglutide in the Liraglutide and Cardiovascular Outcomes in Type 2 Diabetes (LEADER) trial and semaglutide in the Semaglutide and Cardiovascular 
A

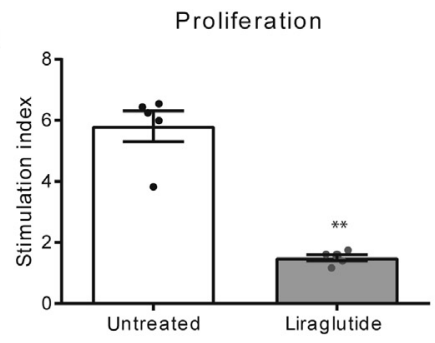

B

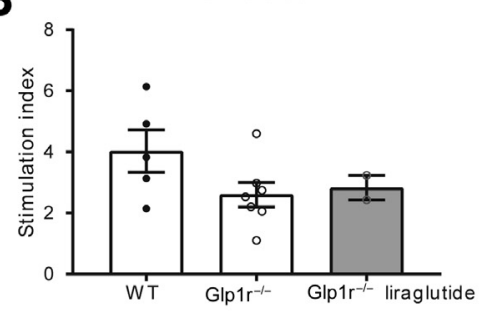

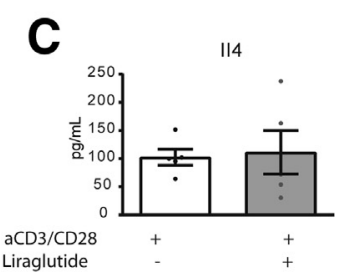

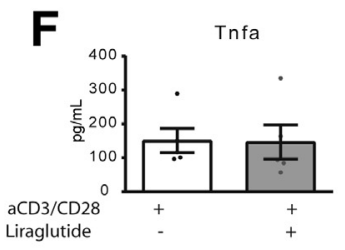

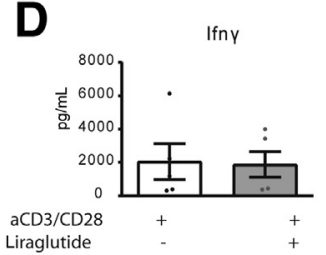

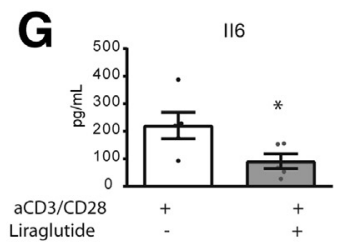

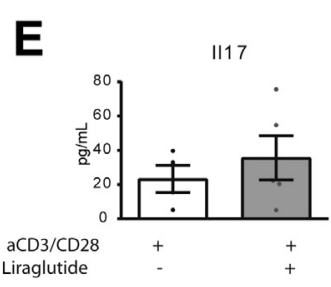

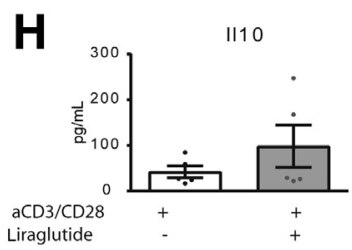

Figure 6 Liraglutide inhibits the proliferation of stimulated mouse $T$ cells and decreases the production of Il- 6 . A: T cells were isolated from $\mathrm{C} 57 \mathrm{BL} / 6 \mathrm{~J}$ mice, stimulated with $\mathrm{aCD} 3 / \mathrm{CD} 28$, and treated with liraglutide in a concentration of $60 \mu \mathrm{g} / \mathrm{mL}$ or vehicle. B: The same procedure was followed for $\mathrm{T}$ cells isolated from $\mathrm{Glp} 1 \mathrm{r}^{-/-}$mice treated with vehicle or liraglutide, which were compared with T cells isolated from WT littermates. A and B: Proliferation of cells was evaluated after 72 hours. The stimulation index is given as the ratio between the optical density values of stimulated to unstimulated cells. $\mathbf{C}-\mathbf{H}$ : The supernatant of the cells was collected after 72 hours, and respective cytokine levels were measured by ELISA. I: TH1 and TH17 polarized cells were treated with liraglutide or vehicle, and proliferation was evaluated after 4 and 5 days, respectively. $n=5$ mice per group $(\mathbf{A})$; $n=2$ liraglutide-treated mice $(\mathbf{B}) ; n=5$ littermates (B); $n=7$ vehicle-treated mice (B); $n=3$ mice per group (I). ${ }^{*} P<0.05$, ${ }^{* *} P<0.01$ versus untreated.

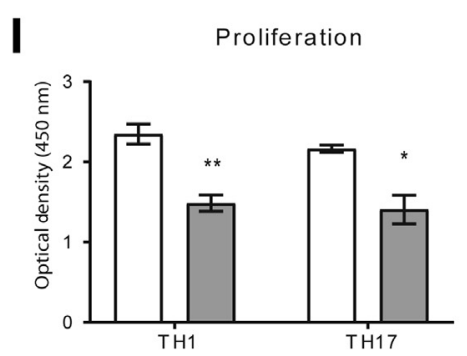

Outcomes in Patients with Type 2 Diabetes 3 (SUSTAIN-6) trial, have shown renal-protective effects. ${ }^{5,22}$ These effects were mainly attributed to a decreased rate of new onset of macroalbuminuria. The mechanisms responsible for this effect are unclear so far, but may involve anti-inflammatory mechanisms induced by GLP1R agonism. ${ }^{7}$ Because the NTS model used throughout the experiments is a model with rapid development of macroalbuminuria dependent on proinflammatory responses in normoglycemic conditions, ${ }^{23}$ it allows us to focus on the antiproteinuric and antiinflammatory capacity of Glp1r agonism.

The anti-inflammatory and immunomodulatory potential of Glp1r agonism was first mentioned in 2010 when Hadjiyanni et $\mathrm{al}^{9}$ provided evidence that peripheral lymphocytes of $\mathrm{Glplr}^{-1-}$ mice display a hyperproliferative response to mitogenic stimuli. In accordance with their observations, Glp1r agonism by liraglutide also decreased the proliferation of T cells in vitro. This was underlined by the authors' in vivo findings in a T-cell-dependent model of NTS.
口Untreated

口 Liraglutide
Liraglutide treatment resulted in fewer proliferating cells in glomeruli as well as within the periglomerular region, where mainly immune cells are found to infiltrate during disease. ${ }^{12,24}$ Furthermore, antigen-specific restimulation with rabbit IgG of splenocytes isolated from $\mathrm{Glplr}^{-/-}$ mice after 14 days of NTS resulted in an increased proliferative response as compared with controls. In line with these findings, TH1 cytokine transcripts were significantly increased in lymph nodes and spleens from Glplr $^{-/}$mice 14 days after NTS induction. Interestingly, alterations were not detected in TH17-related transcripts such as their transcription factor Roryt, which first prompted the authors to hypothesize that signaling via the Glp1r might preferentially influence TH1 cells rather than TH17 cells in NTS. In the in vitro evaluations, only Il- 6 was found to be decreased, whereas other TH1 cytokines such as Ifn- $\gamma$ and the TH17 cytokine Il-17 remained unaltered by liraglutide treatment. The liraglutide effect on proliferation seems to be signaled via the Glp1r, because liraglutide had no effect on 
A

Glycolysis

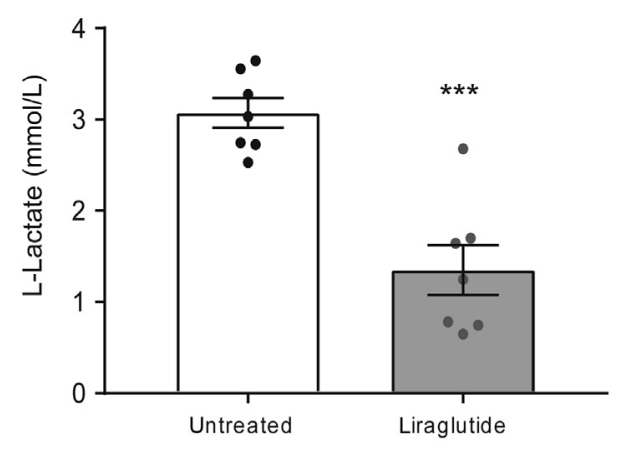

B

Glut1

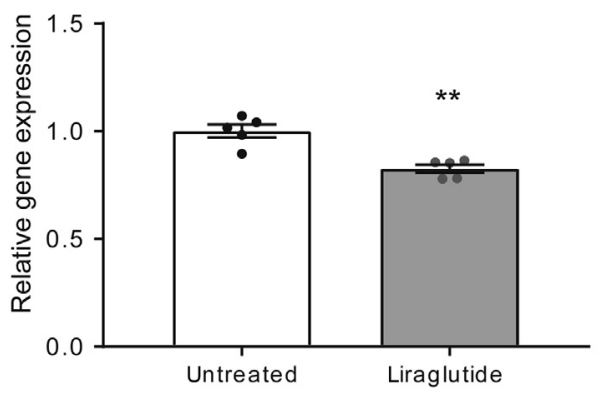

Figure 7 Liraglutide inhibits glycolysis in mouse T cells and downregulates the expression of Glut- 1 . T cells were isolated from $\mathrm{C} 57 \mathrm{BL} / 6 \mathrm{~J}$ mice, stimulated with $\mathrm{aCD} 3 / \mathrm{CD} 28$, and treated with liraglutide in a concentration of $60 \mu \mathrm{g} / \mathrm{mL}$ or vehicle. A: Glycolysis of cells was evaluated after 72 hours. B: The mRNA expression of Glut-1 gene was evaluated in the T cells treated with liraglutide or vehicle. The fold increase compared with the mean mRNA expression in vehicle-treated stimulated T cells is provided. $n=7$ mice per group (A); $n=5$ mice per group (B). ${ }^{* *} P<0.01$, $* * * P<0.001$ versus untreated.

proliferation of $\mathrm{T}$ cells isolated from $\mathrm{Glplr}^{-1-}$ mice. When $\mathrm{T}$ cells were polarized to TH1 and TH17 cells, both were found to express Glplr mRNA. Both polarized T-cell populations showed decreased proliferation when treated with liraglutide, which provides evidence that TH1 and TH17 cells are equally inhibited by liraglutide. It has been proposed that Glp1r agonism might exert its anti-inflammatory potential by increasing the number of peripheral Tregs. ${ }^{9,11,25}$ Because Tregs play a crucial role in limiting disease activity in NTS by acting, not only in the lymph nodes, but also locally within the kidney, ${ }^{12,14,18,26}$ the number of Tregs in Glplr $^{-/-}$ as well as liraglutide-treated mice compared with respective controls were studied after NTS induction, but no differences were observed. Interestingly, both TH1 and TH17 cells have been proven recently to change their glucose metabolism to glycolysis when clonal proliferation is initiated, which is not the case for Tregs. ${ }^{27}$ In vitro stimulated $\mathrm{T}$ cells produced significantly less L-lactate in the presence of liraglutide, which is indicative for a change in their metabolic program resulting in less glycolysis. The blockade of glycolysis by liraglutide might be mediated by a down-regulation of the glucose transporter Glut1, which plays a key mechanism in glycolysis of T cells. ${ }^{27}$ Nevertheless, additional experiments are needed to unravel the regulation of metabolic processes in $\mathrm{T}$ cells by liraglutide because opposing effects have been observed for Glp1r agonism in other cell types such as pancreatic $\beta$-cells and cardiomyocytes. ${ }^{28,29}$

A significantly aggravated NTS phenotype was not observed in $\mathrm{Glplr}^{-1-}$ mice. This is somewhat counterintuitive, because liraglutide significantly reduced the severity of NTS. This finding might be explained by the fact that healthy $\mathrm{Glplr}^{-1-}$ mice have an altered immune system as reflected by decreased lymph node cytokine transcripts, which could have delayed the development of NTS. Hadjiyanni et $\mathrm{al}^{9}$ showed that although peripheral Glp1r deficient $\mathrm{T}$ cells are hyperproliferative, Glp1r-deficient thymocytes showed severely decreased proliferation.

From a clinical perspective, these data provide new insights, not only into anti-inflammatory mechanisms of GLP$1 \mathrm{R}$ agonists, but also into new clinical applications. This study's data support further investigation into the putative role(s) of Glp1r agonism in inflammatory, T-cell-mediated diseases. Besides this observation, Glp1r agonism has already been proven to improve T-cell-mediated murine disease models such as type 1 diabetes and experimental autoimmune encephalitis, ${ }^{25,30,31}$ but clinical data are lacking. The anti-inflammatory effects of liraglutide described in this paper might also partly explain the improved surrogate renal endpoints observed in large randomized control trials in type 2 diabetes patients. ${ }^{4,5,22}$ Preclinical studies provide evidence that immune cells including $\mathrm{T}$ cells play a key role in the development of insulin resistance and diabetic nephropathy. ${ }^{32,33}$ This is supported by clinical data showing that an immune-modulatory drug, bardoxolone, improves kidney function in type 2 diabetic patients with advanced diabetic kidney disease. The clinical picture of diabetic nephropathy and the degree of inflammation varies significantly between each individual with type 2 diabetes, so inhomogeneity of the study cohorts might thereby explain different response rates to tested drugs. ${ }^{34}$

The renal improvement of liraglutide-treated mice subjected to NTS might also be partly explained by the fact that Glp1r agonism suppresses activation of the reninangiotensin-aldosterone system, thereby increasing natriuresis and decreasing blood pressure. ${ }^{35-37}$ In humans, acute administration of GLP1R agonists leads to a transient increase in blood pressure. Chronic administration of liraglutide, however, leads to a modest, but significant, decrease in blood pressure $(-3.59 \mathrm{~mm} \mathrm{Hg}) .{ }^{38}$ Lovshin et $\mathrm{al}^{37}$ studied the hemodynamic effects of liraglutide in patients with hypertension and type 2 diabetes. In their hands, 3-week administration of liraglutide resulted in increased natriuresis without any effect on blood pressure. Because the mice were treated only for a limited time with liraglutide, a blood pressure-lowering effect of liraglutide may not be responsible for the renal-protective 
effect in NTS. Nevertheless, it cannot be excluded that the increased natriuresis and improved renal hemodynamics might add to the protective effects of liraglutide in NTS.

Together, this study provided evidence that Glp1r agonism improves NTS by inhibiting the proliferation of $\mathrm{T}$ cells. The authors findings further explain the renalprotective effects of Glp1r agonism observed in large clinical trials in patients with type 2 diabetes and might open the field for new therapeutic options in T-cell-mediated diseases.

\section{Acknowledgment}

We thank D.J.D. for kindly providing the $G l p 1 r^{-/-}$mice.

\section{Author Contributions}

F.M.F. and M.T. performed experiments and analyzed data; A.H.K. and K.E. designed and performed experiments and analyzed data; M.K., K.A., I.A., C.S., A.A.M., B.F., M.P., T.N., and A.M. performed experiments; D.J.D. provided knock-out mice; T.R.P., P.E., A.R.R., and A.H. designed experiments and analyzed data; all authors wrote and approved the manuscript.

\section{Supplemental Data}

Supplemental material for this article can be found at http://doi.org/10.1016/j.ajpath.2019.10.008.

\section{References}

1. Drucker DJ, Nauck MA: The incretin system: glucagon-like peptide-1 receptor agonists and dipeptidyl peptidase- 4 inhibitors in type 2 diabetes. Lancet 2006, 368:1696-1705

2. Pyke C, Heller SR, Kirk RK, Ørskov C, Reedtz-Runge S, Kaastrup P, Hvelplund A, Bardram L, Calatayud D, Knudsen L: GLP-1 receptor localization in monkey and human tissue: novel distribution revealed with extensively validated monoclonal antibody. Endocrinology 2014, 155:1280-1290

3. Nauck MA, Meier JJ: Incretin hormones: their role in health and disease. Diabetes Obes Metab 2018, 20:5-21

4. Marso SP, Daniels GH, Brown-Frandsen K, Kristensen P, Mann JF, Nauck MA, Nissen SE, Pocock S, Poulter NR, Ravn LS, einberg W, Stockner M, Zinman B, Bergenstal RM, Buse JB; LEADER Steering Committee; LEADER Trial Investigators: Liraglutide and cardiovascular outcomes in type 2 diabetes. N Engl J Med 2016, 375:311-322

5. Mann JF, Ørsted DD, Brown-Frandsen K, Marso SP, Poulter NR, Rasmussen S, Tornøe K, Zinman B, Buse JB; LEADER Steering Committee and Investigators: Liraglutide and renal outcomes in type 2 diabetes. N Engl J Med 2017, 377:839-848

6. Richards P, Parker HE, Adriaenssens AE, Hodgson JM, Cork SC, Trapp S, Gribble FM, Reimann F: Identification and characterization of GLP-1 receptor-expressing cells using a new transgenic mouse model. Diabetes 2014, 63:1224-1233

7. Muskiet MH, Tonneijck L, Smits MM, van Baar M, Kramer MH, Hoorn EJ, Joles JA, van Raalte DH: GLP-1 and the kidney: from physiology to pharmacology and outcomes in diabetes. Nat Rev Nephrol 2017, 13:605-628
8. Bunck MC, Diamant M, Eliasson B, Cornér A, Shaginian RM, Heine RJ, Taskinen M-R, Yki-Järvinen H, Smith U: Exenatide affects circulating cardiovascular risk biomarkers independently of changes in body composition. Diabetes Care 2010, 33: $1734-1737$

9. Hadjiyanni I, Siminovitch K, Danska J, Drucker D: Glucagon-like peptide-1 receptor signalling selectively regulates murine lymphocyte proliferation and maintenance of peripheral regulatory $\mathrm{T}$ cells. Diabetologia 2010, 53:730-740

10. Chaudhuri A, Ghanim H, Vora M, Sia C, Korzeniewski K, Dhindsa S, Makdissi A, Dandona P: Exenatide exerts a potent antiinflammatory effect. J Clin Endocrinol Metab 2012, 97: $198-207$

11. Xue S, Wasserfall CH, Parker M, Brusko TM, McGrail S, McGrail K, Moore M, Campbell-Thompson M, Schatz DA, Atkinson MA, Haller MJ: Exendin-4 therapy in NOD mice with new-onset diabetes increases regulatory T cell frequency. Ann N Y Acad Sci 2008, 1150: $152-156$

12. Eller K, Weber T, Pruenster M, Wolf AM, Mayer G, Rosenkranz AR, Rot A: CCR7 deficiency exacerbates injury in acute nephritis due to aberrant localization of regulatory T cells. J Am Soc Nephrol 2010, $21: 42-52$

13. Wolf D, Hochegger K, Wolf AM, Rumpold HF, Gastl G, Tilg H, Mayer G, Gunsilius E, Rosenkranz AR: CD4+CD25+ regulatory T cells inhibit experimental anti-glomerular basement membrane glomerulonephritis in mice. J Am Soc Nephrol 2005, 16: $1360-1370$

14. Hochegger K, Jansky GL, Soleiman A, Wolf AM, Tagwerker A, Seger C, Griesmacher A, Mayer G, Rosenkranz AR: Differential effects of rapamycin in anti-GBM glomerulonephritis. J Am Soc Nephrol 2008, 19:1520-1529

15. Hopfer H, Holzer J, Hünemörder S, Paust H-J, Sachs M, MeyerSchwesinger C, Turner J-E, Panzer U, Mittrücker H-W: Characterization of the renal CD4+ T-cell response in experimental autoimmune glomerulonephritis. Kidney Int 2012, 82:60-71

16. Summers SA, Steinmetz OM, Li M, Kausman JY, Semple T, Edgtton KL, Borza D-B, Braley H, Holdsworth SR, Kitching RA: Th1 and Th17 cells induce proliferative glomerulonephritis. J Am Soc Nephrol 2009, 20:2518-2524

17. Paust H-J, Turner J-E, Steinmetz OM, Peters A, Heymann F, Hölscher C, Wolf G, Kurts C, Mittrücker H-W, Stahl R, Panzer U: The IL-23/Th17 axis contributes to renal injury in experimental glomerulonephritis. J Am Soc Nephrol 2009, 20:969-979

18. Paust H-J, Ostmann A, Erhardt A, Turner J-E, Velden J, Mittrücker H-W, Sparwasser T, Panzer U, Tiegs G: Regulatory T cells control the Th1 immune response in murine crescentic glomerulonephritis. Kidney Int 2011, 80:154-164

19. Scrocchi LA, Brown TJ, Maclusky N, Brubaker PL, Auerbach AB Joyner AL, Drucker DJ: Glucose intolerance but normal satiety in mice with a null mutation in the glucagon-like peptide 1 receptor gene. Nat Med 1996, 2:1254-1258

20. Rosenkranz AR, Mendrick DL, Cotran RS, Mayadas TN: P-selectin deficiency exacerbates experimental glomerulonephritis: a protective role for endothelial P-selectin in inflammation. J Clin Invest 1999, 103:649-659

21. Kitching RA, Holdsworth SR, Ploplis VA, Plow EF, Collen D, Carmeliet P, Tipping PG: Plasminogen and plasminogen activators protect against renal injury in crescentic glomerulonephritis. J Exp Med 1997, 185:963-968

22. Pfeffer MA, Claggett B, Probstfield JL: Lixisenatide in type 2 diabetes and acute coronary syndrome. N Engl J Med 2016, 374:1094-1096

23. Artinger K, Kirsch AH, Aringer I, Moschovaki-Filippidou F, Eller P, Rosenkranz AR, Eller K: Innate and adaptive immunity in experimental glomerulonephritis: a pathfinder tale. Pediatr Nephrol 2017, 32:943-947

24. Kurts C, Panzer U, Anders H-J, Rees AJ: The immune system and kidney disease: basic concepts and clinical implications. Nat Rev Immunol 2013, 13:738-753 
25. Hadjiyanni I, Baggio LL, Poussier P, Drucker DJ: Exendin-4 modulates diabetes onset in nonobese diabetic mice. Endocrinology 2008, 149:1338-1349

26. Ostmann A, Paust H-J, Panzer U, Wegscheid C, Kapffer S, Huber S, Flavell RA, Erhardt A, Tiegs G: Regulatory T cell-derived IL-10 ameliorates crescentic GN. J Am Soc Nephrol 2013, 24:930-942

27. Palmer CS, Ostrowski M, Balderson B, Christian N, Crowe SM: Glucose metabolism regulates $\mathrm{T}$ cell activation, differentiation, and functions. Front Immunol 2015, 6:1

28. Carlessi R, Chen Y, Rowlands J, Cruzat VF, Keane KN, Egan L, Mamotte C, Stokes R, Gunton JE, de Bittencourt P, Newsholme P: GLP-1 receptor signalling promotes $\beta$-cell glucose metabolism via mTOR-dependent HIF- $1 \alpha$ activation. Sci Rep 2017, 7:2661

29. Wallner M, Kolesnik E, Ablasser K, Khafaga M, Wakula P, Ljubojevic S, Thon-Gutschi E, Sourij H, Kapl M, Edmunds NJ, Kuzmiski BJ, Griffith DA, Knez I, Pieske B, von Lewinski D: Exenatide exerts a PKA-dependent positive inotropic effect in human atrial myocardium GLP-1R mediated effects in human myocardium. $\mathrm{J}$ Mol Cell Cardiol 2015, 89:365-375

30. Li L, Lu J, Jia X, Hui H, Zhang J, Liu Y, Cui W, Xu Q, Zhu D: Liraglutide enhances the efficacy of human mesenchymal stem cells in preserving islet $\beta$-cell function in severe non-obese diabetic mice. Mol Med 2016, 22:800-808

31. DellaValle B, Brix GS, Brock B, Gejl M, Landau AM, Møller A, Rungby J, Larsen A: Glucagon-like peptide-1 analog, liraglutide, delays onset of experimental autoimmune encephalitis in Lewis rats. Front Pharmacol 2016, 7:433
32. Eller K, Kirsch A, Wolf AM, Sopper S, Tagwerker A, Stanzl U, Wolf D, Patsch W, Rosenkranz AR, Eller P: Potential role of regulatory $\mathrm{T}$ cells in reversing obesity-linked insulin resistance and diabetic nephropathy. Diabetes 2011, 60:2954-2962

33. Feuerer M, Hill JA, Mathis D, Benoist C: Foxp3+ regulatory T cells: differentiation, specification, subphenotypes. Nat Immunol 2009, 10:689-695

34. Heerspink HJ, Oberbauer R, Perco P, Heinzel A, Heinze G, Mayer G, Mayer B: Drugs meeting the molecular basis of diabetic kidney disease: bridging from molecular mechanism to personalized medicine. Nephrol Dial Transplant 2015, 30:iv105-iv112

35. Rieg T, Gerasimova M, Murray F, Masuda T, Tang T, Rose M, Drucker DJ, Vallon V: Natriuretic effect by exendin-4, but not the DPP-4 inhibitor alogliptin, is mediated via the GLP-1 receptor and preserved in obese type 2 diabetic mice. Am J Physiol Renal Physiol 2012, 303:F963-F971

36. Kim M, Platt MJ, Shibasaki T, Quaggin SE, Backx PH, Seino S, Simpson JA, Drucker DJ: GLP-1 receptor activation and Epac2 link atrial natriuretic peptide secretion to control of blood pressure. Nat Med 2013, 19:567

37. Lovshin JA, Barnie A, DeAlmeida A, Logan A, Zinman B, Drucker DJ: Liraglutide promotes natriuresis but does not increase circulating levels of atrial natriuretic peptide in hypertensive subjects with type 2 diabetes. Diabetes Care 2015, 38:132-139

38. Sun F, Wu S, Guo S, Yu K, Yang Z, Li L, Zhang Y, Quan X, Ji L, Zhan S: Impact of GLP-1 receptor agonists on blood pressure, heart rate and hypertension among patients with type 2 diabetes: a systematic review and network meta-analysis. Diabetes Res Clin Pract 2015, 110:26-37 